\title{
Economic impacts of the manufacturing industry in Sululta
}

\section{Ekonomski učinci prerađivačke industrije u Sululti}

\begin{abstract}
Manufacturing industries in Ethiopia's urban areas have been overgrowing in the last few decades, which have led to ever-mounting demand for labor, capital, and raw materials. Two questionnaires were independently administered with a representative random sample of 149 members from the local manufacturing industries and 20 high-ranking officials from the study area to answer research questions. Moreover, input-output model was used comprehensively in guesstimating indirect economic impacts of a diversity of activities. Prominent findings from the study indicate that economic impact was extensively dispersed throughout the existing sectors.
\end{abstract}

Keywords: economic development, model, disbursement, quantitative analysis, Ethiopia

\section{JEL classification: E02}

\section{Sažetak}

Prerađivačka industrija u etiopskim urbanim područjima posljednjih nekoliko desetljeća bilježi značajan rast, što je dovelo do sve veće potražnje za radnom snagom, kapitalom i sirovinama. Provedena su dva upitnika i neovisno obrađena s reprezentativnim slučajnim uzorkom od 149 članova iz lokalne proizvodne industrije i 20 visokih dužnosnika s područja istraživanja koji su odgovarali na istraživačka pitanja. Dodatno, sveobuhvatno je korišten input-output model u procjeni neizravnih ekonomskih utjecaja diversifikacije aktivnosti. Istaknuta otkrića studije ukazuju na to da je ekonomski utjecaj bio uvelike disperziran kroz postojeće sektore.

Ključne riječi: ekonomski razvoj, model, izdatak, kvantitativna analiza, Etiopija JEL klasifikacija: E02

\section{Introduction}

In recent years, economic growth has been amplified by regional and local governments in developing and, to some degree, in industrialized countries (Tuček, 2016; Rajnoha and Lesníková, 2016; Povolna and Švarcová, 2017). As a result, there has been a heightened reshuffling of the manufacturing industry (Szalavetz, 2017; Eurostat, 2017), to prop up fiscal development. In Ethiopia, the government has accentuated this growth by supporting regional administrations with sizeable resources to boost local efforts (FDRE and MOFED, 2020). These resources are intended to amplify fiscal growth via planned and monitored reviews (Engeda et al., 2011). Besides, the advantages of boosting the manufacturing industry include: development of other sectors, immediate and positive impact on employment levels, augmented innovation capability, enlarged supply chain, and amplified local trade with service industries. However, these advantages are not trouble-free. In some cases, the efforts have not helped locals due to an influx of immigrant workers - causing social unrest (Tiwari and Rawani, 2012). Moreover, new projects seeking financial backing have received government support and have misused funds

\section{Milkessa Jagemma Tolera}

$\mathrm{PhD}$ candidate at Urban and Regional Planning Program

Ethiopian Institute of Architecture, Building Construction and City Development,Addis Ababa University, Ethiopia

E-mail: milkessa.jagemma@eiabc.edu.et

\section{Hailu Worku}

Prof.

Ethiopian Institute of Architecture, Building Construction and City Development,Addis Ababa University, Ethiopia

E-mail: hailu.worku@eiabc.edu.et

\section{Milkessa Jagemma Tolera}

Doktorski kandidat na Programu urbanog i regionalnog planiranja Etiopski institut za arhitekturu, visokogradnju i razvoj grada, Sveučilište Addis Abeba, Etiopija

E-mail: milkessa.jagemma@eiabc.edu.et

\section{Hailu Worku}

Prof.dr.sc.

Etiopski institut za arhitekturu, visokogradnju i razvoj grada, Sveučilište Addis Abeba, Etiopija

E-mail:hailu.worku@eiabc.edu.et 
Tolera, M. J., Worku, H.

Economic impacts of the manufacturing industry in Sululta
- creating a culture of corruption and mistrust (Mestres, 2017).

Jeon (2006) numerically experienced the hypothesis that the industrialized segment is measured as the steam locomotive of fiscal augmentation in China's case throughout its restructuring epoch of 1979-2004. Besides, projected consequences from both information sets established the Kaldorian suggestion concerning the involvement of the industrialized segment towards fiscal development in China during its transformation epoch. Felipe et al. (2007) executed an investigation of structural conversion of mounting Asia's augmentation practice all through the decades of 1970s, 80, plus 90 s. The nearly all well-known attribute of this alteration was found to be a noteworthy begoff in the farming distribution alongside with the analogous boost in the distribution of services in GDP. According to the anticipated consequences, both firm and services added in fiscal growth. A number of substantiations of endogenous growthinduced scientific advancement was also practical in the case of budding Asia.

Moreover, Chakravarty and Mitra (2009) found that the manufacturing sector's responsibility as an engine of development and depicted the interconnection between numerous manufacturing activities. Based on the consequences, the manufacturing segment emerged to be one of the burly determinants of general fiscal intensification besides production and services sectors.

The rationale of this research was to gauge not merely the direct monetary outcomes but also the derived or indirect outcomes of manufacturing industries. Whereas the fiscal reorganization that has risen over the long-ago decade has led some residents to scrutinize exported products (MartinPena and Diaz-Garrido, 2008), manufacturing is still the alternative most habitually believed by societies looking for monetary expansion and diversification. Besides, up-to-date practice in Sululta specifies that manufacturing may still be a convenient basis of intensification for the countryside and built-up areas. From 2012 to 2018, the town's manufacturing employment augmented by $16 \%$ (237 works), with nearly all villages of the city recording sizeable gains (ORSAB, 2020).

Further, several studies have dealt with growth incentives to shape industry start-ups and extensions or capability replacements (Lamastra et al., 2018). Merely a little has dealt with the direct impacts of skill growth or extension, plus less up to now be scrutinized the indirect outcomes of industries of diverse sorts. The findings of this research indicated that economic impact was extensively dispersed throughout the existing sectors.

Lastly, in this article, input-output model was used to capture the indirect economic impacts of manufacturing industries and descriptive statistics was used to describe the existing situations in the study area. The rest of this study is prearranged as follows. In part two, the method is presented with the processes of input-out model that are used in capturing indirect economic impacts. In part three, an experimental inquiry, results, discussion and recommendation are carried out on study vicinity.

\section{Methods and materials}

Data needed to carry out the study was attained throughout a survey, carried out in 2020 in Sululta, Oromia, Ethiopia, about $30 \mathrm{~km}$ north of Addis Ababa. The survey was organized by cross-referencing a catalog of manufacturers collected by the Sululta municipality Department of Planning and Finance with an analogous record organized by the Sululta municipality Office of Social Affairs. The target was to attain the mainly inclusive coverage and promising of the city's manufacturing segment. Since the research aimed to recognize attributes and desires of industrialized industries that were supporting deals outdoor the town, industries that supplied merely neighborhood trades (e.g., producers of neighborhood) were purged as of the record.A sum of 103 firms was found, but form these, 23 industries were purposely selected, touched and reacted to the surveys. Nevertheless, just 19 of these (or $82 \%$ of the inhabitants) offered the entire data requisite for the fiscal effect scrutiny reported here. They were investigating these participants' attributes contrasted to these of industries that, and to indirect data for the town's industrialized segment, specified that the participants were delegated to the town's producers.

The industries were inquired to offer a diversity of data, together with recent employ, employ 
seven years former to the investigation, real trades, the allotment of disbursements by kind (i.e., for unprocessed objects, processed resources, undeviating work and subcontracting), and the proportion of disbursement which was completed to entities inside the town. In order to guesstimate the derived fiscal outcomes of the diverse kinds of industries, the guesstimates of all industries intown disbursements were related to the Sululta municipality Input-Output Model (Coon et al., 1984). Input-output models have been used lengthily in guesstimating a diversity of projects and plans (Otto and Johnson, 1993). Depending on every industry's in-town disbursement, the input-output model offered guesstimates of the entire monetary effect result from its yearly operations.

Besides, to supplement and defy quantitative data concerning the economic impacts of the manufacturing industry, interviews were carried out with 43 stakeholders directly involved in operating the manufacturing industry in Sululta town. Interviewed stakeholders included government administrators, public-private association experts, residents, aged people, communal activists, and industry owners. Interviews were conducted from September to December 2020 in a semi-structured format. Besides interview were exploited to recognize the continuation and character of the economic impacts of the manufacturing industry.

\section{Literature review}

The function of manufacturing as a driver of economic growth in developing nations has been the subject of several empirical investigations. Szirmai and Verspagen (2015) used fixed and random effects to examine the link between manufacturing's value-added share and GDP per capita growth, and for an imbalanced panel of 92 nations, Hausman-Taylor estimations and between-effects models were used. This link was investigated for three time periods: 1950-1970, 1970-1990, and 1990-2005, and the results were compared to the service sector's outcomes. Szirmai and Verspagen's study examines the contribution of manufacturing to GDP per capita growth as a function of education and stage of development, focusing largely on the results of conservative Hausman-Taylor estimations. They locate that manufacturing acts as a locomotive of development for stumpy and for some middle earnings countries provided they have an adequate stage of human capital. Such growth engine traits are not seen for the service industry. Interestingly, the data for more recent times imply that a greater level of human capital (at least 7-8 years of schooling) is required for manufacturing to fulfill the function of locomotive of development in developing countries. Necmi (1999) used an instrumental variable econometric technique for 45 predominantly developing nations from 1960 to 1994 to see if Kaldor's (1967) conclusions were still relevant after the 1970s heydays of rapid industrialization and catch-up. With the probable exception of SubSaharan Africa, the findings supported 4 Kaldor's claim that "industry is an engine of growth" in the majority of developing countries studied. McCausland and Theodossiou (2012) found that Kaldor's thesis held true for the period 1992-2007 in developed countries as well.

McMillan et al. (2014) discussed the driving nature of manufacturing, how successful regions have changed their structure to benefit from this driver of economic growth, and whether this path of economic development is still open to currently developing countries in a series of recent publications (McMillan et al., 2014).

This series illustrates that labor productivity in the formal manufacturing sector increased rapidly and unconditionally, and that Asian countries grew faster than other regions by shifting labor from low to high-productivity sectors, particularly manufacturing. Rodrik, on the other hand, is gloomy about the current economic development pattern for developing countries due to premature deindustrialization.

\section{Results}

\subsection{Quantitative analysis of economic impacts of the manufacturing industry in Sululta}

Selected attributes of the sample industry are annotated in Table 1. Of the 23 industries, around $5.2 \%$ had been fashioned in 2012 or extra freshly (i.e., less than seven years former to the assessment). Around $55 \%$ had been fashioned
Tolera, M. J., Worku, H.

Economic impacts of the manufacturing industry in Sululta 
Tolera, M. J., Worku, H.

Economic impacts of the manufacturing industry in Sululta

Table 1 Selected characteristics of Sululta Town manufacturing industries, 2020

\begin{tabular}{|c|c|c|c|c|}
\hline Characteristics & $\begin{array}{l}\text { Number of } \\
\text { firms (no.) }\end{array}$ & Percent of sample (\%) & Gross sales (million) & $\begin{array}{l}\text { Percent of products } \\
\text { sold out of the city (\%) }\end{array}$ \\
\hline All industries & 23 & 78 & 71 & 42.1 \\
\hline New industries & 7 & 5.2 & 5.4 & 49.3 \\
\hline \multicolumn{5}{|c|}{ Firms established more than } \\
\hline$<25$ employees & 38 & 55 & 12 & 35.3 \\
\hline 25 or $>25$ employees & 27 & 24 & 9.3 & 23.5 \\
\hline \multicolumn{5}{|l|}{ Types of products } \\
\hline Durable goods & 35 & 49.2 & 7 & 39 \\
\hline Non-durable goods & 26 & 31.3 & 4 & 29.5 \\
\hline High-tech firms & 8 & 34 & 3 & 19 \\
\hline Agribusiness firms & 11 & 13 & 2.1 & 12 \\
\hline \multicolumn{5}{|l|}{ Types of establishments: } \\
\hline Only location of firm & 66 & 100 & 71 & 42.1 \\
\hline Headquarter of the firm & - & - & - & - \\
\hline Branch plant & - & - & - & - \\
\hline
\end{tabular}

Source: Field survey (2020).

former to 2012 and had less than 25 workers seven years former to the survey, whereas around $24 \%$ had been fashioned former to 2020 and had 25 or extra employees seven years former to the survey.

About $1 / 3$ of the respondent industries were durable goods manufacturers. Agribusiness industries made up about $13 \%$ of the sample, as well as these industries were about unequally separated among nondurable goods manufacturers (mostly food processors) and resilient products manufacturers. In addition, Tukey test indicates that industries with less than 25 employees are significantly different from those with 25 or more at $\alpha=0.05$. Besides, agribusiness industries are extensively different from other industries at a 0.05 (Tukey test). More than $95 \%$ of the participants revealed that their start was the only vicinity of their industry. Furthermore, the respondent industries reported that the entire trades in 2020 that summed up 72 million, with $42.1 \%$ of their trades being completed unswervingly to out-of-region entities (Table 1). Participants that narrated moderately lofty average trades incorporated with high-tech industries and agribusiness industries. And, Agribusiness industries and high-tech industries reported that comparatively lofty fractions of out-of- region trades, and by establishments with 25 or extra workers seven years former to the investigation. Updated-fangled industries (produced in 2020 or extra lately) as well announced elevated than a middling out-of-town deal.
Moreover, the sample industry announced that labor made up around $28 \%$ of their entire disbursements, whereas unprocessed products (27 $\%)$ and produced products (25\%) were besides major spending items (Table 2). The proportion of an industry's disbursements that are completed inside the neighborhood vicinity, otherwise inside the region, straightforwardly influences the amount to which these districts would practice indirect economic impacts. And the respondents pointed out that most of their work disbursements were prepared inside the region where the capability was positioned, plus nearly all (97 \%) were made inside the municipality subcontracting as well as extra disbursements were as well made principally to entities inside the town. Further, the majority of expenditures for finished materials and unprocessed products were to entities exterior the town. Generally, the industries exposed that $50 \%$ of their expenditures were made inside the town as well as $69 \%$ inside the region.

The respondent industries also fluctuated significantly regarding up-to-date employment stages and the numeral of works they had produced in the previous seven years. The sample industries employed a middling of 44 personnel at the occasion of the investigation (Table 3). A little hefty sector had a key pressure on this number; nevertheless, the median industry's up-to-date employ was 15 The industries had produced a middling of 12 works throughout the previous seven years, with a 
Table 2 Sharing of disbursements by respondent industries, 2020

\begin{tabular}{|l|c|c|c|}
\hline \multicolumn{1}{|c|}{ Expenditure category } & \% of total disbursement & Location of supplier & Out of the town (\%) \\
\hline Raw materials & 27 & 13 & 87 \\
\hline Processed materials & 25 & 5 & 95 \\
\hline Labor & 28 & 90 & 10 \\
\hline Subcontracting & 12 & 54 & 46 \\
\hline Other & 8 & 12 & 88 \\
\hline
\end{tabular}

Source: Field survey (2020).

Table 3 Existing career and works created in the last seven years in Sululta

\begin{tabular}{|c|c|c|c|c|}
\hline \multirow[t]{2}{*}{ Characteristics } & \multicolumn{2}{|c|}{ Existing career } & \multicolumn{2}{|c|}{$\begin{array}{c}\text { Job produced in the previous seven } \\
\text { years }\end{array}$} \\
\hline & Mean & Median & Mean & Median \\
\hline All industries & 44 & 15 & 12 & 8 \\
\hline New industries & 14 & 11 & 11 & 7 \\
\hline \multicolumn{5}{|c|}{$\begin{array}{l}\text { Firms established more than seven } \\
\text { years: }\end{array}$} \\
\hline$<25$ employees & 12 & 10 & 4.7 & 3.2 \\
\hline 25 or $>25$ employees & 37 & 25 & 22 & 19 \\
\hline \multicolumn{5}{|l|}{ Types of products } \\
\hline Durable goods & 35 & 22 & 30 & 18 \\
\hline Non-durable goods & 45 & 18 & 25 & 21 \\
\hline High-tech firms & 31 & 35 & 29 & 10 \\
\hline Agribusiness firms & 34 & 23 & 19 & 23 \\
\hline \multicolumn{5}{|l|}{ Types of establishments: } \\
\hline Only location of firm & 27 & 16 & 23 & 19 \\
\hline Headquarter of the firm & - & - & - & - \\
\hline Branch plant & - & - & - & - \\
\hline
\end{tabular}

Source: Field survey (2020).

middle value of 8 . Bearing in mind all industries, $12 \%$ narrated that their employment had lessened in the precedent seven years; whereas $9 \%$ had no alteration in employment. Besides, a few industries had produced significant amounts of works. Of the sample industries, the peak $5 \%$ (in the amount of works produced) had produced $58 \%$ of the entire results (Field survey, 2020). Those conclusions are analogous to Povolna and Švarcová (2017), who exposed that between groups of petite manufacturers in northern England, $6 \%$ of the industries had produced $34 \%$ of the jobs.

Field survey (2020) signifies that amongst the peak industries in work establishment ( $4 \%$ of the sample or five industries), every however solitary were resilient product producers. Besides, all industries were positioned in the study area (Sululta Town), while three were independent operations. Only one had been established inside the precedent seven years, and merely one was a high-tech industry. When deeming the number of works created by industries of diverse kinds, new-fangled industries (created in the preceding seven years) had created a middling of 14 jobs per industry, while all industries that had been recognized further than seven years produced a middling of 12 works (Table 3). The recognized industries that had 25 or more jobs seven years former to the investigation had produced a middling of 22 jobs, which symbolized an augment of $36 \%$. The recognized industries with fewer than 25 jobs had created around 5 jobs on middling, representing a boost of about $54 \%$. When deeming the sum numeral of jobs created, nevertheless, the fresh industries accounted for barely $6.6 \%$ of the entire jobs created by all industries in the cram, whilst the hefty recognized industries (with 25 or extra employees seven years ahead of) accounted for $14 \%$ and their slighter counterparts for $3 \%$.

Amongst additional industry classifications, the agribusiness industries had produced a mediocre of 19 jobs per industry or as well of $17.3 \%$ over the
Tolera, M. J., Worku, H.

Economic impacts of the manufacturing industry in Sululta 
Tolera, M. J., Worku, H.

Economic impacts of the manufacturing industry in Sululta

Table 4 Sum disbursements, \% of disbursements within the town, and out of town per direct job, 2020

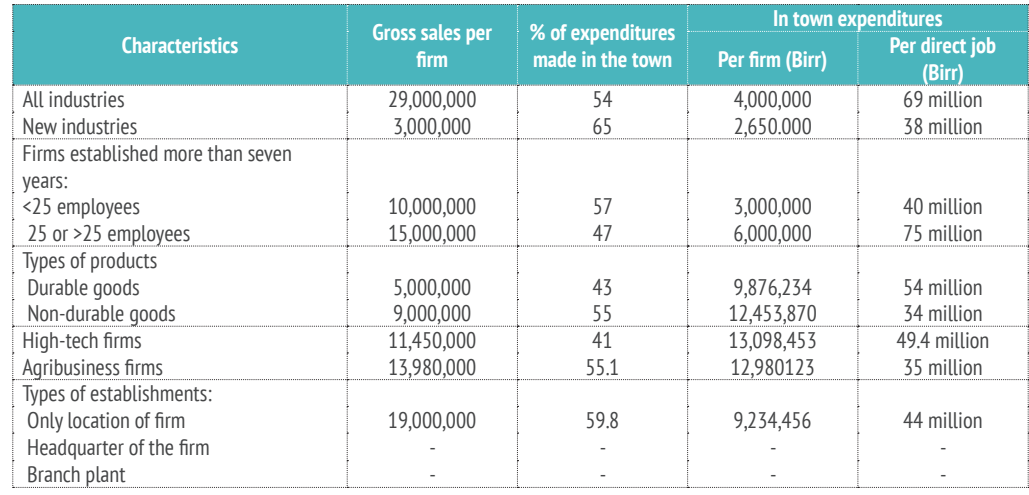

Source: Field survey (2020).

Table 5 Derived employment and entire fiscal impact of manufacturing industries, 2020

\begin{tabular}{|c|c|c|c|c|}
\hline \multirow[b]{2}{*}{ Characteristics } & \multicolumn{2}{|c|}{ Derived employment } & \multicolumn{2}{|c|}{ Overall fiscal impacts } \\
\hline & Per industry(no.) & $\begin{array}{l}\text { Per direct work } \\
\text { (no.) }\end{array}$ & Per industry (Birr.) & $\begin{array}{l}\text { Per direct work } \\
\text { (Birr.) }\end{array}$ \\
\hline All industries & 138 & 5.2 & $14,095,345$ & $7,341,090$ \\
\hline New industries & 9 & 0.6 & $8,345,456$ & $4,560,980$ \\
\hline \multicolumn{5}{|c|}{$\begin{array}{l}\text { Firms established more than seven } \\
\text { years: }\end{array}$} \\
\hline$<25$ employees & 15 & 1.3 & $2,345,213$ & $1,236,098$ \\
\hline 25 or $>25$ employees & 520 & 4 & $29,345,245$ & $10,876,210$ \\
\hline \multicolumn{5}{|l|}{ Types of products } \\
\hline Durable goods & 127 & 2.5 & $7,574,231$ & $1,234,067$ \\
\hline Non-durable goods & 209 & 4.3 & $5,093,401$ & $2,341,095$ \\
\hline High-tech firms & 33 & 1.4 & $3,786,345$ & $12,345,010$ \\
\hline Agribusiness firms & 249 & 5.2 & $11,209,345$ & $7,012,401$ \\
\hline \multicolumn{5}{|l|}{ Types of establishments: } \\
\hline Only location of firm & 104 & 2.4 & $4,010,397$ & $2,039,491$ \\
\hline Headquarter of the firm & - & - & - & - \\
\hline Branch plant & - & - & - & - \\
\hline
\end{tabular}

Source: Field survey (2020).

previous seven years (Table 3). High-tech industries had produced a mediocre of 29 works, a swell of about $17 \%$

The fraction of disbursements that the diverse types of industries made within the municipality is concluded in Table 4. Generally, the industry found that about $54 \%$ of their sum disbursements were made inside the town. Industry that had been recognized inside the previous seven years exposed the uppermost rate of in municipality disbursements (69 \%). Established industry with less than 25 workers seven years before the investigation had an extensively elevated fraction of expenditures inside the municipality than their complements with elevated employ stages. High-tech industries had a considerably lesser percentage of disbursements to entities inside the region than other industries. This could be accredited to the elevated proportion of the components they procured from out-of-town providers.

Whilst the industry's in-town disbursements were separated by their entire employ at the occasion of the investigation (undeviating works), generous deviations were renowned. In general, 
Table 6 Undeviating disbursements and sum financial effect of Sululta producers, by monetary segment, middling per industry

\begin{tabular}{|l|c|c|}
\hline \multicolumn{1}{|c|}{ Sector } & Undeviating expenditures (in birr) & $\begin{array}{c}\text { Economic impact (Entire business } \\
\text { volume }\end{array}$ \\
\hline Agriculture & $12,034,234$ & $4,082,109$ \\
\hline Transportation & $9,091,231$ & $3,903,405$ \\
\hline Communication and public utilities & $5,509,270$ & $1,230,970$ \\
\hline Finance, insurance and real estate & $8,209,105$ & $3,254,106$ \\
\hline Services & $10,230,129$ & $4,123,098$ \\
\hline Households & $14,234,345$ & $1,098,103$ \\
\hline Other & - & - \\
\hline Total & $59,308,314$ & $17,691,791$ \\
\hline
\end{tabular}

Source: Field survey (2020).

the investigated industries exposed a middling of about 69 million of in-town disbursements per undeviating work (that is, per individual engaged by the industry) (Table 4). Industries produced inside the precedent seven years, nevertheless, narrated merely 38 million in-town disbursements per direct work. Established industries with 25 or more workers seven years proceeding to the survey also had a significantly elevated stage of in-town disbursements per undeviating worker than their complements with fewer workers. Producers of perishable products had significantly elevated stages of in-town disbursements than resilient goods manufacturers. High-tech industries had lofty stages of in-town buys per direct worker, whereas those of agribusiness industry were pretty stumpy.

When the industry's in-town disbursements were related to the correlation coefficients of the Sululta Town input-output model, guesstimates of the entire trade quantity (entire receipts) consequential in diverse segments of the municipality economic system were attained. Guesstimates of the stage of entire receipts requested in every segment to hold up one supplementary work (entire trade volume to employment proportions) were then concerned to the guesstimates of extra entire business volume to attain guesstimates of the derived employment resulting from the manufacturers' disbursements (Brown and Greenbaum, 2017). The sum derived employment and sum entire business volume in every segment resulting from the industries' disbursements are summed up in Table 5.

The Sululta town manufacturers amounted for a middling of 138 derived jobs, or 5.2 derived works per undeviating work (that is, an employ raiser of 2.6) (Table 5). Significant deviations seen nevertheless, amongst industries of diverse kinds. Industries that had been started further than seven years plus had 25 or extra workers seven years proceeding to the examination amounted for 520 derived works per industry as well as 4 derived jobs per undeviating work. Their counterparts through less than 25 workers seven years earlier had barely 1.3 derived works per direct worker (15 works per industry), and industries created within the precedent seven years had merely 0.6 derived works per direct worker ( 9 works per industry). Nondurable products manufacturers had a significantly superior number of derived works per direct work (4.3) than their complements employed in resilient products manufacturing (2.5). Besides, agribusiness industries establishments as well witnessed moderately lofty stages of derived works per undeviating work.

The entire trade dimensions produced in every segment of the Sululta municipality financial system as a consequence of the manufacturers' functions and disbursements summed up $14,095,345$ Birr per industry or about 7,341,090 per direct work (Table 5). Deviations in entire trade dimensions (entire fiscal effect) per industry and per direct work amongst industries of diverse kinds were analogous to those reported for derived employment. The direct disbursements and entire economic impact of Sululta town manufacturers' operations were extensively disseminated across the diverse segments of the town's economy (Table 6). Segments that obtained hefty undeviating disbursements incorporated households (payrolls and earnings preserved inside the town), agricultural processing plus miscellaneous manufacturing (processed materials
Tolera, M. J., Worku, H.

Economic impacts of the manufacturing industry in Sululta 
Tolera, M. J., Worku, H.

Economic impacts of the manufacturing industry in Sululta
Figure 1 Responses from respondents' as to economic impacts of manufacturing industries

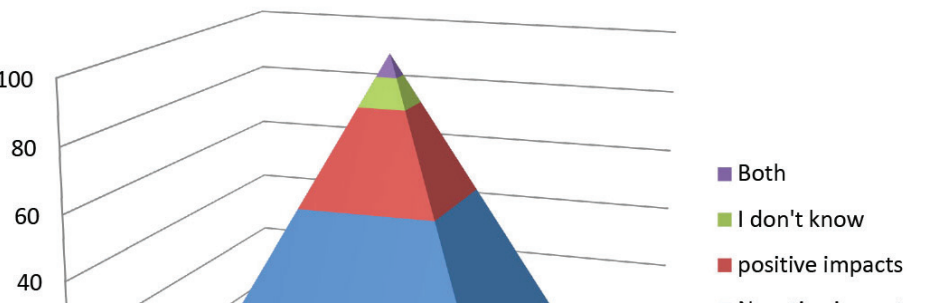

negative impacts
Source: Field survey (2020).

and subcontracts), agricultural materials), finance, insurance and real estate (worker benefits and trade insurance). Segments that obtained hefty total impact incorporated services, agriculture, finance, insurance and real estate retail. The entire business volume of the household segment is fundamentally equal to private revenue of town inhabitants. Therefore, the middling manufacturing industry donated more than one million birr yearly to the private earnings of Sululta town inhabitants. The retail segment added almost 5.5 million birr in the entire business amount due to the middling manufacturer's functions, with almost 87 $\%$ of this happening as a consequence of derived results. Generally, the direct and derived monetary outcomes of manufacturing were broadly dispersed amongst the other sectors of the Sululta town economic system.

\subsection{Qualitative analysis of economic impact of manufacturing industry in Sululta}

Interview facts verify that manufacturing industry has been a universal incidence in Sululta town over the precedent 10 years, particularly in the epoch amid 2005 and 2012. Respondents confirmed that the actual trades patterns recognized for some particular industries (such as allied and Immuye food complex PLC) and pointed out additional industries where both positive and negative impact has happened. Two respondents tidily separated economic impact of manufacturing industry into two categories: negative impact, leads to an increase cost of living and greater demand for local food and crafts; and positive impact: increase in household income and government revenues and promoting government policies.Although economic impact (negative and positive) was universal, some respondents quarreled that the "window" for lucrative manufacturing industries were quite petite, commonly from 2005 to 2012; besides, some proprietors who had manufacturing industry had accurately planned to promote the life of residence but were enticed to sell by skyrocketing product prices and willing buyers.

Some onlookers understood that the manufacturing industry pronouncement was the prevalent reason in boosting financier curiosity, as it agreed over 5,000 fresh employees in Sululta town. One observer at the occasion distinguished that local consumption-food; prices had previously mounted $35 \%$ since some of these communal statements and mourned the looming leeway of an extra barren sequence of economic impact of the sort that has left the innermost town with so much high-priced products. Further, interview data revealed that yet manufacturing industry holders 
still handled to purchase and turn over a number of neighboring products, raising local products prices enormously in the progression. Survey result indicate that vigorous manufacturing investment based on communal outlays may have predated these plans, studying trades of input and output products and surrounding proposed investments, observed that annual sales raised by $35 \%$ in the seven years following the preliminary allied industry pronouncement (2000-2008).

Hence, accordingly, the responses from questionnaires show that about $54 \%$ of the local residents in one way or another feel that manufacturing industries have negative impacts (increasing living costs) for the local residents. However, $30 \%$ of the local stakeholders feel that local manufacturing industries' establishments have positive impacts (revenue generation and job creation) for local and regional residents (Figure 1). They expect that during the establishments of local manufacturing industry their land will be taken by the town administration at any occasion when it is looked-for to built-up local development programs. That means most people in neighborhood periurban societies are uncertain about how long their property will remain theirs.

\section{Conclusion}

As neighboring and regional governments institutes turn out to be more engaged in economic improvement plans, truthful data regarding the direct and indirect results of industry start-ups and extensions becomes gradually more significant. The result of the study revealed that there were significant disparities between industries of different kinds as consider both undeviating as well as indirect fiscal effects. Besides, a frequently used determinant of undeviating is the numeral of works produced by diverse kinds of industries (Birch,1987; Gallagher and Stewart, 1986; Bollard and Harper, 1986; Harrison, 1994). Findings of this research stated that the industries had produced a middling of 12 works in excess of the precedent seven years. Around $73 \%$ of the industries explained that their general employment had augmented contrasted to seven years ahead of whilst $9 \%$ found no alteration and $18 \%$ exposed dwindled employ. A little industry had a key pressure on the general job formation figures-the peak $4 \%$ of the industries (in amount of works produced) produced $64 \%$ of the entire jobs. These conclusions recommend that communal plans that give practical or fiscal backing to manufacturers may gain from data that could permit industries with lofty job-creation prospective to be recognized and beleaguered for extraordinary backing. A number of researchers have annotated that fresh industries as well as/ otherwise petite industries have been answerable for a suspiciously hefty fraction of network formation (Dasgupta and Singh, 2005), but the conclusions of this research recommend merely half-done back up. Surrounded by the illustration, diminutive industries (fewer than 20 workers) had an elevated rate of employ augmentation in excess of the precedent seven years than their superior complements. Nevertheless, they related for merely $37 \%$ of the total jobs produced, contrasted to 54 $\%$ for the bigger industries. New-fangled industries produced more jobs per industry, on middling, than older industries, but they accounted for only $7 \%$ of the whole jobs produced as a cluster. Therefore, these conclusions are likely to back up the outlook that an unbiased loom to fiscal progress might be additional suitable than are striated depend on diminutive industries or new-fangled start-ups (Libanio, 2006). Industries differed significantly not just in their undeviating effect however too with reverence to their derived fiscal effect. Industries that made considerable disbursements inside the municipality amounted for elevated stages of indirect employment and for augmented entire business volumes in diverse regions of the town economic scheme. In addition, industry types that had the peak stages of derivative effect per direct job were hefty recognized industries i.e., agribusiness industries. When estimating desires for economic backing and motivation growth, clusters may desire to inquiry industries regarding their strategies to engage more in neighborhood entities as suppliers. Brokerage associations intended to humanize the connection among producers as well as prospective in-town suppliers would have prospective for mounting producers' contributions to regional and neighboring economic systems. Lastly the major findings of this article are as follows: 1) Tukey test indicates that industries with less than 25 employees are significantly different
Tolera, M. J., Worku, H.

Economic impacts of the manufacturing industry in Sululta 
Tolera, M. J., Worku, H.

Economic impacts of the manufacturing industry in Sululta from those with 25 or more at $a=0.05 .2$ ); In average manufacturing industry donated more than one million birr yearly to the local inhabitants; 3) The direct expenditure and total economic impact were extensively dispersed throughout the existing sectors; 4) Perhaps the most prominent finding of the research, nevertheless, worries the sizeable extent of the direct and secondary economic impacts of manufacturing functions. The firms studied made direct expenditures to other entities within the state economy that summed almost $14,095,345$ Ethiopian birr or about 7,341 per direct job. The total impact averaged 42,092.456 Ethiopian birr annually per firm, or 21,000 Ethiopian birr per direct job.

\section{References}

Brown, L., \& Greenbaum, R. T. (2017). The role of industrial diversity in economic resilience: An empirical examination across 35 years. Urban Studies, 54,1347-1366. https://doi.org/10.1177/0042098015624870

Birch, D. L. (1987). Job Creation in America: How Our Smallest Companies Put the Most People to Work. The Free Press.

Bollard, A., \& Harper, D. (1986). Employment generation and establishment size in New Zealand manufacturing. International Small Business Journal: Researching Entrepreneurship, 4(4), 10-28. https://doi.org/10.1177/026624268600400401

Chakravarty, S., \& Mitra, A. (2009). Is Industry still the engine of growth? An econometric study the organized sector employment in India. Journal of Policy Modeling, 31(1), 22-35. https://doi.org/10.1016/j.jpolmod.2008.06.002

Coon, R. C., Leholm, A. G., Leistritz, F. L. \& Hertsgaard, T.A. (1984). The North Dakota input-output model: a tool for measuring economic linkages. North Dakota farm research, 42(2), 36-39.

Dasgupta, S., \& Singh,A. (2005). Will Services be the new engine of Economic Growth in India? (Working Paper No. 310). Center for Business Research, University of Cambridge.

Engeda, E., Beyene, S.,Alemayehu, E., Debowicz, D., Dorosh, P., \& Robinson, S. (2011). ESSP II Working Paper 30 Ethiopia's Growth and Transformation Plan: A Computable General Equilibrium Analysis of Alternative Financing Options. Development Strategy and Governance Division, International Food Policy Research Institute - Ethiopia Strategy Support Program II, Ethiopia, SSRN Electronic Journal.

Eurostat (2017, June). Manufacturing statistics-NACE Rev.2. European Commission.

Federal Democratic Republic of Ethiopia (FDRE), \& Ministry of Finance and Economic Development (MOFED) (2020). Ethiopia: Sustainable Development and Poverty Reduction Program. Federal Democratic Republic of Ethiopia (FDRE),Addis Ababa Ethiopia.

Felipe, J.,León-Ledesma,M.,Lanzafame,M., \& Estrada, G.(2007). Sectoral Engines of Growth in Developing Asia: Stylized Facts and Implications (ERD Working Paper Series No. 107). Asian Development Bank, ERD (Economic and research department).

Gallagher,C.C., \& Stewart,H.(1986).Jobs and the business life-cycle in the U.K. Applied Economics, 18(8), 875-900.https://doi.org/10.1080/00036848600000048

Harrison, B. (1994). The myth of small firms as predominant job generators. Economic Development Quarterly, 8(1), 3-18. https://doi.org/10.1177/089124249400800101 
Jeon, Y. (2006). Manufacturing, Increasing returns and economic development in China, 1979-2004: A Kaldorian Approach (Working paper No. 2006-08). University of Utah, Department of Economics. https://econ.utah.edu/research/publications/2006_08.pdf (10.6.2021).

Kaldor, N. (1967). Strategic Factors in Economic Development. New York State School of Industrial and Labor Relations, Cornell University.

Lamastra, L., Suciu, N. A., \& Trevisan, M. (2018). Sewage sludge for sustainable agriculture: contaminants' contents and potential use as fertilizer. Chemical and Biological Technologies in Agriculture, 5(1), 10. https://doi.org/10.1186/s40538-018-0122-3

Libanio, G. (2006, December). Manufacturing Industry and Economic Growth in Latin America: A Kaldorian Approach [Conference presentation]. Second Annual Conference for Development and Change, Campos Do Jordaº, Brazil. https://www.networkideas.org/ideasact/jun07/Beijing_Workshop_07/Gilberto_Libanio.pdf (10.6.2021).

Martin-Pena,M.L., \& Diaz-Garrido,E.(2008).Topologies and taxonomies of operations strategy: a literature review. Management Research News, 31(3), 200-218. https://doi.org/10.1108/01409170810851294

McCausland, D. W., \& Theodossiou, I. (2012). Is Manufacturing Still the Engine of Growth? Journal of Post Keynesian Economics, 35(1), 79-93. https://doi.org/10.2753/PKE0160-3477350105

McMillan, M., Rodrik, D., \& Verduzco, I. (2014). Globalization, Structural Change, and Productivity Growth, With an Update on Africa. World Development, 63,11-32. http://dx.doi.org/10.1016/j.worlddev.2013.10.012

Mestres, J. (2017). Infrastructure in the European Union and the Juncker Plan. Dossier: Investment in infrastructure MR03, CaixaBank Research, 23,123-130.

Necmi, S. (1999). Kaldor's Growth Analysis Revisited. Applied Economics, 31, 653-660. https://doi.org/10.1080/000368499324093

Oromia Regional State Social Affairs Bureau - ORSAB (2020). Regional working paper. Department of Planning, Addis Ababa, Ethiopia.

Otto,D.M., \& Johnson,T.G.(1993).Microcomputer-based input-output modeling: Applications to economic development. Boulder: Westview Press, 81-197. https://doi.org/10.1201/9780429033797

Povolná, B., \& Švarcová, J. (2017).The Macroeconomic Context of Investments in the Field of Machine Tools in the Czech Republic. Journal of Competitiveness, 9(2),110-122. https://doi.org/10.7441/joc.2017.02.08

Rajnoha, R., \& Lesníková, P. (2016). Strategic Performance Management System and Corporate Sustainability Concept - Specific Parameters in Slovak Enterprises. Journal of Competitiveness, 8(3), 107-124. https://doi.org/10.7441/joc.2016.03.07

Szalavetz, A. (2017). Intangible investments at multinational companies' manufacturing subsidiaries: do they promote innovation-based upgrading? Equilibrium. Quarterly Journal of Economics and Economic Policy, 12(1), 63-80. https://doi.org/10.24136/eq.v12i1.4

Szirmai,A., \& Verspagen, B. (2015). Manufacturing and Economic Growth in Developing Countries, 19502005. Structural Change and Economic Dynamics, 34,46-59. https://doi.org/10.1016/j.strueco.2015.06.002

Tiwari, J. K., \& Rawani, A. M. (2012). Environmental impact analysis: Case studies of ACC cement plant. Journal of Environmental Research and Development, 7(2), 130-136.

Tuček, D. (2016). Process Segmentation Typology in Czech Companies. Journal of Competitiveness, 8(1), 79-94. https://doi.org/10.7441/joc.2016.01.06 
